\title{
Mating behavior of house mice of Trans-Caucasian hybrid zone: a comparative study with parent species Mus musculus
}

\author{
Alexander V. Ambaryan \& Elena V. Kotenkova*
}

\begin{abstract}
The functional significance of the different types of social behavior in total as well as distinct elements of these behavior, are shaped by factors derived mainly from individual, gender and speciesspecific characteristics. We analyzed which of these factors (or all of them) affect features of mating behavior in dyadic encounters of con- and heterospecific partners in two closely related forms of house mice - Mus musculus and mice from hybrid zone of Trans-Caucasia. There are two sources of the polymorphism in the gene pool of Trans-Caucasian mice: the ancient (stemmed from relict origin of the genetic pool) and evolutionarily new (derived from gene flows from differentiated taxa: M. domesticus and M. musculus). We revealed that sex is the main factor determining the level of aggression during dyadic encounters of sexual partners. It has been shown that species-specific behavioral patterns are the only factor that determines some of the main quantitative parameters of the male's sexual behavior. These include the frequency of ejaculation and the rate of mounts with intromission, which are definitive for the successful copulation. As we have shown earlier species-specific features in the patterns of sexual behavior, which appear during encounters of heterospecific males and females belonging to the closely related taxa of house mice, may provoke the incomplete or the unsuccessful copulation. This means that differences in the main quantitative parameters of male's mating behavior may represent (on an evolutionary scale) one of the driving forces behind the reproductive isolation of Trans-Caucasian mice of hybrid origin from M. musculus.
\end{abstract}

How to cite this article: Ambaryan A.V., Kotenkova E.V. 2020. Mating behavior of house mice of Trans-Caucasian hybrid zone: a comparative study with parent species Mus musculus // Russian J. Theriol. Vol.19. No.2. P.149-160. doi: 10.15298/rusjtheriol.19.2.05.

KEY WORDS: hybrid zone, Trans-Caucasian house mice, Mus musculus, mating behavior.

AlexanderV.Ambarian [aambaryan@gmail.com],ElenaV.Kotenkova [evkoytenkova@yandex.ru], Institute of Ecology and Evolution RAS, Leninskiy prospect 33, Moscow 119071, Russia.

\section{Половое поведение домовых мышей из зоны гибридизации Закавказья: сравнение с родительским видом Mus musculus}

\section{А.В. Амбарян, Е.В. Котенкова}

РЕЗЮМЕ. Функциональная значимость разных типов социального поведения, а также отдельных элементов социального поведения определяется факторами, которые зависят от разных форм идентичности индивидов: их индивидуальной специфичности, а также половой и таксономической идентичности. Мы проанализировали, какие формы идентичности влияют на особенности брачного поведения при ссаживаниях кон-и гетероспецифических партнеров у двух близкородственных форм домовых мышей - Mus musculus и мышей из зоны гибридизации Закавказья. Существует два источника полиморфизма в генофонде закавказских мышей: древний (обусловленный реликтовым происхождением генофонда) и эволюционно новый (обусловленный потоками генов от дифференцированных таксонов: M. domesticus и M. musculus). Мы выявили, что половая идентичность является основным фактором, определяющим уровень агрессивности в парных встречах сексуальных партнеров. Показано, что таксономическая идентичность является единственным фактором, определяющим некоторые основные количественные параметры полового поведения самца (частоту эякуляций, частоту садок с интромиссией), которые в то же время являются определяющими для успешного совокупления. Таксономические особенности в паттернах полового поведения, проявляющиеся при встречах гетероспецифичных самцов и самок близкородственных таксонов домовых мышей, могут приводить к неполному или нерезультативному спариванию. Это означает, что различия в основных количественных параметрах полового поведения самцов могут представлять (в эволюционном плане) одну из движущих сил репродуктивной изоляции гибридных мышей из Закавказья и M. musculus.

КЛЮЧЕВЫЕ СЛОВА: зона гибридизации, домовые мыши из Закавказья, M. musculus, половое поведение. 


\section{Introduction}

One of the most promising areas of evolutionary research is the significance of hybridization in speciation and diversification of mammals. The evolutionary aspects of hybridization of animals, including comparison of the behavior of hybrids and individuals of parental taxa, have been intensively studied (Arnold, 1997; Barton, 2001; Hewitt, 2001; Borkin \& Litvinchuk, 2013). The data obtained in recent decades have shown that the hybridization of species and subspecies was and still is of great importance in evolution, including the speciation of mammals. It has been described in $6 \%$ of European species (Rieseberg, 1997; Barton, 2001; Mallet, 2007; Baack \& Rieseberg, 2007; Comeault \& Matute, 2018). Other researchers and we have repeatedly discussed the systematics of Mus musculus s. lato (Rodentia: Muridae) (Sage et al., 1993; Bonhomme et al., 1994; Maltsev et al., 2016). The group of commensal taxa of Mus musculus s. lato superspecies complex includes $M$. m. musculus, M. m. domesticus and M. m. castaneus. According to one approach, these taxa are subspecies (Boursot et al., 1993). According to the alternative point of view, they are classified as species: Mus musculus Linnaeus, 1758, M. domesticus Schwartz et Shwartz, 1943, M. castaneus Waterhouse, 1842, but after Sage et al. (1993: 523-561) we consider them as distinct species. Representatives of commensal taxa hybridize in zones of their contacts. The narrow (16-50 km) hybrid zone of Central Europe is a well-studied "tension zone" of secondary contact of M. musculus and M. domesticus (Boursot et al., 1993; Sage et al., 1993), in which selection against hybrids is documented (Britton-Davidian et al., 2005; Albrechtová et al., 2012; Turner et al., 2012). In this hybrid zone a pattern of reproductive character displacement and a possibility of "agonistic character displacement" as result of reinforcement, was demonstrated (Smadja \& Ganem, 2005; Bímová et al., 2011; Latour \& Ganem, 2017). According to the authors of this study these kinds of displacement may not be a potential driver of subspecies recognition. There may be another mechanism involved that drives formation of taxa recognition in house mice (Latour \& Ganem, 2017).

Hybrid zones of synanthropic species of house mice vary significantly in size, genetic structure, and evolutionary history. The extensive hybrid zone in Trans-Caucasia is one of the most complexes, according to the history of formation, in its spatial and genetic structure (Orth et al., 1996; Mezhzherin et al., 1998; Milishnikov et al., 2004). Trans-Caucasian populations of synanthropic house mice possess an admixture of M. musculus and M. domesticus genes (Mezhzherin \& Kotenkova, 1989; Milishnikov et al., 1990; Mezhzherin et al., 1998). For these reasons, some authors consider this area as a zone of secondary contact between $M$. musculus and $M$. domesticus, with very wide introgression of $M$. domesticus genes into the genome of $M$. musculus (Mezhzherin \& Kotenkova, 1989; Frisman et al., 1990; Mezhzherin et al., 1998). However, Milishnikov et al. (2004: 1011-1027) consider house mice of Trans-Cau- casia as relict populations descended from non-differentiated forms with ancestral polymorphism (Milishnikov et al., 2004). To date, existing data do not support the hypothesis of secondary contact of differentiated forms of house mice in this region (Milishnikov et al., 2004). The approach developed by Milishnikov (2004: 317-320) tries to resolve the apparently conflicting data about the phylogenetic origin and the implication of gene flows on the gene pool of mice from Trans-Caucasia. The approach assumes two sources of the polymorphism in the gene pool of mice from Trans-Caucasia: the ancient (stemmed from the relict origin of the genetic pool) and evolutionarily new (derived from gene flows from the differentiated taxa-M. domesticus and M. musculus). The proposed hypothesis suggests and justifies that the Trans-Caucasian populations of house mice are carriers of the relict gene pool (Milishnikov et al., 2004).

Trans-Caucasia is an extensive territory largely isolated by natural barriers from other geographical regions. These barriers are the Black and Caspian seas and the large Caucasus Mountains in the north, which cut off this territory from the area of $M$. musculus. This is confirmed by the fact that the North Caucasian populations of house mice are $M$. musculus. They are characterized by a complete set of standard diagnostic characters of this taxon: the tail is shorter than body length, light-colored belly, a sharp border between the color of back and abdomen, and the absence of allozyme diagnostic alleles of $M$. domesticus (Mezhzherin et al., 1998). The natural barriers of Trans-Caucasia are also the Pontic Mountains from the North-West, the Armenian highlands from the West and South-West and the Iranian Plateau from the South. This means that area can to some extent be considered as refuge, in which the ancestral form of house mice had been preserved and adapted to local conditions for a long time without mixing (or mixing to a limited extent) with populations of mice from neighboring regions. The process of adaptation may have been accompanied by changes in social structure and behavior. Well-known plasticity of the house mice social structure (which varies considerably throughout the entire range depending on local conditions) (Walkowa et al., 1998; Kotenkova \& Munteanu, 2006) may be an additional factor contributing to these changes.

It should be noted that the main features and consecutive stages of sexual behavior are conservative and very similar in different synanthropic taxa (Ambaryan et al., 2015) and strains (Park, 2011) of house mice. There are significant differences in the number of different behavioral acts and interactions in dyadic encounters of sexual partners. The full expression of mouse copulation may be achieved only if females are in the estrus stage, which is an increased period of sexual activity that occurs around the time of ovulation (Niel \& Monks, 2013). Sequential hormonal changes associated with ovulation initiate alterations in the nervous system of females that permit the expression of female-typical sexual behavior, including increased locomotion and seeking of sexual partners. The initial phases of copulation include investigation by males of the anogenital 
region of the females and following of females. At the same time, estrus females seek contact with males by approaching and remaining in close proximity to males. These behavioral interactions contribute to increased male arousal to the point where mounting is initiated. After that a copulatory series starts, which consists of several bouts of activity (Mosig \& Dewsbury, 1976). In each bout, a male will mount an estrus female, grasping her flanks with his forepaws and engaging in relatively rapid pelvic thrusting. Female behavior consists simply of assuming a reflexive posture in response to male mounts, termed lordosis. Lordosis is achieved by arching of the back and reflection of the tail, which allows for penile intromission. In successful mounts, the male will insert his penis into the female's vagina (mounts with intromission) to accomplish deeper and slower pelvic thrusting. After each bout, males will engage in genital grooming and rest for several seconds or minutes before the next mount. At the final stage of series mounts with intromissions and thrusts (potentially dozens of mounts with hundreds of thrusts across an ejaculatory series), males will ejaculate. At the end of ejaculation, the pair often will fall over together and remain immobile for several seconds. The units of male sexual behavior that are involved in copulatory series are therefore mounts, intromissions, and ejaculations. All these behavioral elements are included in our analysis.

It has been shown that many of the quantitative measures of male copulatory behavior vary markedly within several inbred strains of house mice (McGill, 1962; Batty, 1978a, b). Males of four inbred strains (BALB/c, $\mathrm{CBA} / \mathrm{H}, \mathrm{DBA} / 2 \mathrm{~J}, \mathrm{C} 57 \mathrm{BL} / 6 \mathrm{Fa}$ ) can be classified as low-frequency mounters (BALB/c, $\mathrm{CBA} / \mathrm{H})$, medium frequency mounters (DBA/2J), and high-frequency mounters (C57BL/6Fa and BDF1) (Batty, 1978a, b). In addition, males from pigmented strains possessed a greater sexual vigor compared to the males of albino strains. The differences of males of the FVB/NtacfBR and C57BL/6J strains encompass the level of sexual aggression and frequency of copulation during mating with FVB/NtacfBR stimulus females (Canastar \& Maxson, 2003). During encounters with estrus females, FVB/ NtacfBR males exhibited more aggression and fewer copulatory behaviors than C57BL/6J males.

Three inbred strains (C57BL, BALB/c, and DBA/2J) of laboratory mice differ in 12 out of 16 measures of male sexual behavior (McGill, 1962). The sharpest behavioral differences were noted between males of two strains $\mathrm{C} 57 \mathrm{BL} / 6 \mathrm{~J}$ and $\mathrm{DBA} / 2 \mathrm{~J}$. Males of $\mathrm{C} 57 \mathrm{BL} / 6 \mathrm{~J}$ strain exhibited shorter latencies to mount and mount with thrust and shorter intervals between intromissions. Also, in $\mathrm{C} 57 \mathrm{BL} / 6 \mathrm{~J}$ males intromissions and thrusts appeared more frequently than in $\mathrm{DBA} / 2 \mathrm{~J}$ males. $\mathrm{DBA} / 2 \mathrm{~J}$ males initiated sexual behavior later, but ejaculation occurred in those males after fewer thrusts and intromissions than in the other two strains. In addition, only males of that strain demonstrated aggression toward the females after the ejaculation.

Interstrain variability in sexual behavior characteristics, including quantitative differences in frequency, duration or succession of copulatory series behavioral elements, indicates that these differences may be significant factors of selection and may have influence on the early stages of reproductive isolation and speciation. Also, behavior that immediately precedes and follows the mating bout is likely to be involved in coordinating male-female interactions (Beach, 1976), as well as establishing the succession and temporal components of different parts of the mating cycles (Stopka \& Macdonald, 1998, 1999), and as a result can be important in precopulatory isolation (Ambaryan et al., 2019).

A significant difference in both the quantitative manifestation of behavioral acts and the appearance of new elements was previously shown when comparing patterns of hunting behavior in closely related species of hamsters (Levenets et al., 2019) and voles (Panteleeva et al., 2020). The study reported here investigated mating behavior divergence between natural hybrids from Trans-Caucasia and one of parental species M. musculus. We hypothesized that partial geographic isolation may contribute to the divergence of the sexual behavior patterns of the Trans-Caucasian mice and $M$. musculus, which in turn can complicate communication and diminish the odds of mating success between potential partners of these taxa. In evolutionary scale this process can contribute to narrowing or attenuation of gene flow of M. musculus into this zone. We tested the hypothesis that the sexual behavior of Trans-Caucasian mice and M. musculus can differ in intensity.

\section{Materials and methods}

\section{Mouse origin and maintenance}

This work was carried out using the collection of animals from the Living Collection of Wild Mammalian Species of the Common Science Center (Institute of Ecology and Evolution, Russian Academy of Sciences). Mice were performed at the Chernogolovka Scientific and Experimental Center (Institute of Ecology and Evolution, Russian Academy of Sciences). Test subjects were adult at the age of 3-6 months 46 males and 49 females of M. musculus trapped in Moscow as well as laboratory-reared individuals $\left(\mathrm{F}_{1}-\mathrm{F}_{5}\right.$ generations); 39 males and 43 females from Yerevan city (Trans-Caucasia) ( $F_{1}-F_{3}$ generations). According to previously obtained data, the mice from Yerevan and Moscow used in this study possessed mtDNA of M. musculus. Mice from the Trans-Caucasia formed a separate clade on phylogenetic trees (constructed by Bayesian analysis) and in haplotype networks (split network and the median network) (Maltsev et al., 2015). It was demonstrated earlier that all mice samples from Trans-Caucasia, including Yerevan city, had hybrid origin (Mezhzherin \& Kotenkova, 1989; Orth et al., 1996; Mezhzherin et al., 1998) with admixture of genetic pool from $M$. musculus as well as from $M$. domesticus. All mice were housed in standard plastic cages measuring $29 \times 19 \times 13 \mathrm{~cm}$ at least 10 days prior the experiments, which contained sawdust, food (special mixed fodder for mice, Russia) and water $a d$ 
libitum. Males were maintained singly; females were kept in groups of three-four individuals. All mice were sexually experienced.

\section{Experimental design and behavior registra- tion}

The experimental design was developed by us earlier when comparing the sexual behavior of $M$. musculus and M. spicilegus Petényi, 1882 and was described in details in previous publications (Ambaryan \& Kotenkova, 2008; Ambaryan et al., 2015). We performed dyadic encounters of male and estrus female. The stage of estrus was identified evaluating cytology of vaginal smears (Nelson et al., 1982). The estrus was induced by sequential injections of estrogen and progesterone (McGill, 1962; Estep et al., 1975). Total number of tests was 45 (male M. musculus $\times$ female $M$. musculus, $n=15$; male mice from Trans-Caucasia $\times$ female mice from Trans-Caucasia, $n=$ 10; male M. musculus $\times$ female mice from Trans-Caucasia, $n=10$; male mice from Trans-Caucasia $\times$ female M. musculus, $n=10$ ). Behavioral tests were conducted in clear glass chambers $(50 \times 25 \times 30 \mathrm{~cm})$ that were divided by partition into two equal compartments. Male and female were transferred from their cages in small boxes in different parts of the chamber. The habituation period was 6 hours. The test and recording of male and female behavior started with removal of the partition. If no intromissions occurred within 30 min after beginning of the observation test was interrupted and not included for analysis. Standard duration of the test was $90 \mathrm{~min}$ if patterns of sexual behavior were initiated within first $30 \mathrm{~min}$. In all 45 tests included in analysis at least one ejaculation occurred, while other tests with incomplete sexual behavior or tests without any element of sexual behavior were excluded from data pool. Behavior of the mice was recorded by means of video camera Sony Digital. Data analysis was made by means of Observer Video-Pro - professional system for collection, analysis, presentation and management of observational data (Noldus, The Netherlands). According to software guide each behavioral element was assigned specific key combination on keyboard.

Behavioral elements were divided into three classes (Dewsbury et al., 1979; Mackintosh, 1981; Kotenkova et al., 1989a with modifications; Niel \& Monks, 2013): sexual behavior (attempts of mounts, mounts with intromissions, mounts without intromissions, mounts with intromissions and thrusts, genital lock, ejaculations); agonistic behavior (fighting, attacks, threat posture, reciprocal upright, pushing, submissive posture, circle round the partner, sideways posture, jumping with pushing the partner, jumping over the partner, boxing, chase, rattle of the tail) and affiliative behavior (naso-nasal, naso-anal contacts, investigation of different parts of the body of the partner, following, crawl over partner, approaching, grooming of the partner, exposure for grooming, crowding, stretched approaching, sniffing). When processing data all behavioral elements (except sexual behavior elements) was pooled in to total frequency and dura- tion of two behavioral classes: affiliative behavior and aggressive behavior.

\section{Statistical analysis}

In our analysis we considered following factors that may have effect on frequency and duration of behavior: individual's sex, taxon and type of encounter (conspecific or heterospecific). As method of analysis we employed nonparametric ANOVA (Jamovi ver.1.1.9). This type of analysis employs a calculation of robust alternative of the arithmetic means which can be defined as the class of trimmed means (containing the sample median as a special case). A trimmed mean discards a certain percentage at both ends of the distribution. We accepted trim at level 0.1. Intergroup differences were estimated using Kruskal-Wallis one-way analysis of variance test, while pairwise comparisons were performed by using nonparametric Mann-Whitney and Wilcoxon tests ("SigmaPlot for Windows ver.14.0"). Post-hoc comparisons after Kruskal-Wallis test were made by using Dunn test. We accept a level of significance as $p<0.05$, and in the tables we give medians.

\section{Ethical note}

All experiments with mice were performed in accordance with the ABS/ASAB guidelines for the ethical treatment of animals. The Bioethical Committee of Institute of Ecology and Evolution, Russian Academy of Sciences approved the experimental protocol (No. 3, 2017-06-19). We were particularly committed to limit the number of mice tested and to reduce their stress as much as possible: 1) during habituation period mice had food, water and nest material; 2) we transferred the mice from their cage to the chamber and back in special small boxes into which they entered themselves, the mice left them in the chamber also themselves; 3 ) in experiments, the elements of sharp aggression were rare, inspection of animals after the experiment showed the absence of any injuries; 4) we did not observed any abnormal behavior among the mice during and after completion of our study.

\section{Results}

\section{Factor analysis of three types of behavior} (aggressive, affiliative and sexual)

Results of our experiments indicate, that sex of the individual is the only factor that affects frequency and duration of aggressive behavior during encounters of con- or heterospecific sexual partners of house mice (Tab. 1,2 , accordingly). At the same time different factors affect frequency and duration of affiliative behavior in that encounters. Frequency of affiliative behavior depends on individual's taxon and sex (Tab. 3). Farther more, interaction of factors of taxon and type of encounters is also highly influential for frequency of affiliative behavior. Duration of affiliative behavior depends on factor of type of encounters and interaction of factors of taxon and type of encounters (Tab. 4). Taxon was also decisive 
Table 1. Factorial analysis of the frequency of aggressive behavior.

\begin{tabular}{|l|c|c|}
\hline \multicolumn{1}{|c|}{ Main effects and interactions } & Test statistic $(\mathrm{Q})$ & $p$ \\
\hline taxon & 3.023 & 0.096 \\
\hline sex & 41.966 & $0.001^{*}$ \\
\hline type of encounter & 0.038 & 0.848 \\
\hline taxon - sex & 2.918 & 0.102 \\
\hline taxon - type of encounter & 0.237 & 0.632 \\
\hline sex - type of encounter & 0.023 & 0.881 \\
\hline taxon - sex - type of encounter & 0.215 & 0.648 \\
\hline
\end{tabular}

Table 2. Factorial analysis of the duration of aggressive behavior.

\begin{tabular}{|l|c|c|}
\hline \multicolumn{1}{|c|}{ Main effects and interactions } & Test statistic (Q) & $p$ \\
\hline taxon & 1.387 & 0.260 \\
\hline sex & 31.890 & $0.001^{*}$ \\
\hline type of encounter & 0.622 & 0.440 \\
\hline taxon - sex & 1.304 & 0.267 \\
\hline taxon - type of encounter & 0.190 & 0.668 \\
\hline sex - type of encounter & 0.563 & 0.462 \\
\hline taxon - sex - type of encounter & 0.163 & 0.691 \\
\hline
\end{tabular}

Table 3. Factorial analysis of the frequency of affiliative behavior.

\begin{tabular}{|l|c|c|}
\hline \multicolumn{1}{|c|}{ Main effects and interactions } & Test statistic (Q) & $p$ \\
\hline taxon & 5.205 & $0.028^{*}$ \\
\hline sex & 6.078 & $0.018^{*}$ \\
\hline type of encounter & 2.470 & 0.124 \\
\hline taxon - sex & 3.950 & 0.054 \\
\hline taxon - type of encounter & 8.548 & $0.006^{*}$ \\
\hline sex - type of encounter & 0.643 & 0.428 \\
\hline taxon-sex - type of encounter & 0.294 & 0.591 \\
\hline
\end{tabular}

Table 4. Factorial analysis of the duration of affiliative behavior.

\begin{tabular}{|l|c|c|}
\hline \multicolumn{1}{|c|}{ Main effects and interactions } & Test statistic (Q) & $p$ \\
\hline taxon & 2.932 & 0.097 \\
\hline sex & $<0.001$ & 0.992 \\
\hline type of encounter & 5.533 & $0.025^{*}$ \\
\hline taxon - sex & 0.960 & 0.335 \\
\hline taxon - type of encounter & 6.210 & $0.018^{*}$ \\
\hline sex - type of encounter & 0.381 & 0.542 \\
\hline taxon - sex - type of encounter & 0.338 & 0.565 \\
\hline
\end{tabular}

factor for three elements of sexual behavior: frequency of ejaculation, frequency of genital lock and mounts with intromission (Tab. 5). Duration of sexual behavior as well as frequency of other elements of that type of behavior did not influenced by any factors, which are included in our analysis (Tab. 6).
Intergroup differences according to category of taxon, sex, and type of encounter for all three types of behavior

There were no differences between individuals of two taxonomic forms in frequency and duration of aggressive behavior (Tab. 7). There were no differences in frequency 
Table 5. Factorial analysis of the frequency of ejaculation, genital lock and mounts with intromission.

\begin{tabular}{|l|c|c|}
\hline \multicolumn{1}{|c|}{ Main effects and interactions } & Test statistic (Q) & $p$ \\
\hline type of encounter & ejaculation & 0.121 \\
\hline taxon & 2.60 & $0.043^{*}$ \\
\hline taxon - type of encounter & 4.63 & 0.294 \\
\hline \multicolumn{3}{|c|}{ genital lock } \\
\hline type of encounter & 1.16 & 0.873 \\
\hline taxon & 0.027 & $0.028^{*}$ \\
\hline taxon - type of encounter & 6.058 & 0.873 \\
\hline & 0.027 & 0.187 \\
\hline type of encounter & 1.92 & $0.036^{*}$ \\
\hline taxon & 5.34 & 0.187 \\
\hline taxon - type of encounter & 1.92 & \\
\hline
\end{tabular}

Table 6. Factorial analysis of the duration of sexual behavior and the frequency of attempts to mount, mounts without intromission and mounts with intromission and thrusts.

\begin{tabular}{|l|c|c|}
\hline \multicolumn{1}{|c|}{ Main effects and interactions } & Test statistic (Q) & $p$ \\
\hline \multicolumn{1}{|c|}{ duration of sexual behavior } & 0.062 \\
\hline type of encounter & 3.834 & 0.739 \\
\hline taxon & 0.114 & 0.575 \\
\hline taxon - type of encounter & 0.324 & 0.231 \\
\hline \multicolumn{2}{|c|}{ attempts to mount } \\
\hline type of encounter & 1.596 & 0.168 \\
\hline taxon & 2.163 & 0.484 \\
\hline taxon - type of encounter & 0.526 & 0.665 \\
\hline \multicolumn{1}{|c|}{ mounts without intromission } \\
\hline type of encounter & 0.192 & 0.965 \\
\hline taxon & 0.002 & 0.307 \\
\hline taxon - type of encounter & 1.086 & 0.694 \\
\hline \multicolumn{2}{|c|}{0.158} & 0.948 \\
\hline type of encounter & 0.004 & 0.314 \\
\hline taxon & 1.056 & \\
\hline taxon - type of encounter &
\end{tabular}

and duration of aggressive behavior between individuals that encountered with heterospecific or conspecific sexual partners. Females were more aggressive toward partners than males in all encounters (Tab. 7). Individuals of M. musculus and mice from Trans-Caucasia were not different in the frequency and duration of affiliative behavior (Tab. 8). Duration of that type of behavior was longer in conspecific encounters than in heterospecific ones (Tab. 8). This relation was not influential for frequency of affiliative behavior. Males and females in all types of encounters were not different in frequency and duration of affiliative behavior (Tab. 8).

Frequency of attempts of mount in males did not depend on type of encounter and taxon (Tab. 9). But frequency of ejaculation, mounts with intromission and genital lock in males of $M$. musculus were greater than in males of mice from Trans-Caucasia. At the same time duration of sexual behavior was longer in conspecific encounters than in heterospecific ones (Tab. 9). In all other cases differences in frequency of sexual behavior elements by category of taxon and type of encounters were not significant (Tab. 9).

\section{Discussion}

The results of our investigation show that general pattern of mating behavior is the same in two forms of house mice: M. musculus and mice from Trans-Caucasia. Females were more aggressive toward partner than males in M. musculus and in mice from Trans-Caucasia. Ritualized aggression toward males may stimulate their sexual motivation and attempts to mount, or allow fe- 
Table 7. Differences in aggressive behavior by categories of sex, taxonomic identity and type of encounter.

\begin{tabular}{|c|c|c|c|c|c|c|}
\hline \multirow[b]{2}{*}{ Paired comparisons } & \multicolumn{3}{|c|}{ Frequency of behavior } & \multicolumn{3}{|c|}{ Duration of behavior } \\
\hline & Median & $\begin{array}{l}\text { Mann-Whitney } \\
\text { test U statistic }\end{array}$ & $\begin{array}{c}\text { The level of } \\
\text { significance }(p)\end{array}$ & $\begin{array}{l}\text { Median (sec- } \\
\text { onds) }\end{array}$ & $\begin{array}{l}\text { Mann-Whitney } \\
\text { test U statistic }\end{array}$ & $\begin{array}{l}\text { The level of } \\
\text { significance } \\
(p)\end{array}$ \\
\hline $\begin{array}{l}1-\text { M. musculus, } \\
2-\text { mice from } \\
\text { Trans-Caucasia }\end{array}$ & $\begin{array}{c}1-46 \\
2-5\end{array}$ & 697.5 & 0.324 & $\begin{array}{c}1-21.54 \\
2-1.98\end{array}$ & 718 & 0.431 \\
\hline $\begin{array}{l}1 \text { - conspecific } \\
\text { partner, } \\
2 \text { - heterospecific } \\
\text { partner }\end{array}$ & $\begin{array}{c}1-27 \\
2-5.50\end{array}$ & 758.5 & 0.692 & $\begin{array}{l}1-11.8 \\
2-2.82\end{array}$ & 736,5 & 0.542 \\
\hline \multirow{2}{*}{$\begin{array}{l}1 \text { - males, } \\
2 \text { - females }\end{array}$} & Median & $\begin{array}{l}\text { Wilcoxon Z } \\
\text { statistic }\end{array}$ & $\begin{array}{l}\text { The level of } \\
\text { significance }(p)\end{array}$ & $\begin{array}{l}\text { Median } \\
\text { (seconds) }\end{array}$ & $\begin{array}{l}\text { Wilcoxon Z } \\
\text { statistic }\end{array}$ & $\begin{array}{l}\text { The level of } \\
\text { significance } \\
\qquad(p)\end{array}$ \\
\hline & $\begin{array}{c}1-1 \\
2-165\end{array}$ & 5.511 & $<0.001 *$ & $\begin{array}{c}1-0.2 \\
2-61.54\end{array}$ & 5.511 & $<0.001^{*}$ \\
\hline
\end{tabular}

Table 8. Differences in affiliative behavior by categories of sex, taxonomic identity and type of encounter.

\begin{tabular}{|c|c|c|c|c|c|c|}
\hline \multirow[b]{2}{*}{ Paired comparisons } & \multicolumn{3}{|c|}{ Frequency of behavior } & \multicolumn{3}{|c|}{ Duration of behavior } \\
\hline & Median & $\begin{array}{l}\text { Mann-Whitney } \\
\text { test U statistic }\end{array}$ & \begin{tabular}{|c|} 
The level of \\
significance $(p)$ \\
\end{tabular} & $\begin{array}{l}\text { Median } \\
\text { (seconds) }\end{array}$ & $\begin{array}{c}\text { Mann-Whitney } \\
\text { test U statistic }\end{array}$ & $\begin{array}{c}\text { The level of } \\
\text { significance }(p)\end{array}$ \\
\hline $\begin{array}{l}1-\text { M. musculus, } \\
2-\text { mice from } \\
\text { Trans-Caucasia }\end{array}$ & $\begin{array}{l}1-396 \\
2-299\end{array}$ & 634 & 0.111 & $\begin{array}{l}1-527.74 \\
2-412.06\end{array}$ & 690 & 0,292 \\
\hline $\begin{array}{l}1 \text { - conspecific } \\
\text { partner, } \\
2 \text { - heterospecific } \\
\text { partner }\end{array}$ & $\begin{array}{l}1-342.5 \\
2-312.5\end{array}$ & 706 & 0,368 & $\begin{array}{l}1-580.96 \\
2-397.54\end{array}$ & 587 & $0.041 *$ \\
\hline \multirow[b]{2}{*}{$\begin{array}{l}1 \text { - males, } \\
2 \text { - females }\end{array}$} & Median & $\begin{array}{l}\text { Wilcoxon Z } \\
\text { statistic }\end{array}$ & $\begin{array}{c}\text { The level of } \\
\text { significance }(p)\end{array}$ & $\begin{array}{l}\text { Median } \\
\text { (seconds) }\end{array}$ & $\begin{array}{l}\text { Wilcoxon Z } \\
\text { statistic }\end{array}$ & $\begin{array}{c}\text { The level of } \\
\text { significance }(p)\end{array}$ \\
\hline & $\begin{array}{c}1-373 \\
2-295.5\end{array}$ & -1.761 & 0.079 & $\begin{array}{l}1-405.5 \\
2-504.26\end{array}$ & -0.0134 & 0.995 \\
\hline
\end{tabular}

males to select males which are stronger or are ready to copulate with them. Affiliative behavior of mice depends on all three factors derived from experimental conditions. These factors (taxon, sex and type of encounters) affect duration as well as frequency of the affiliative behavior. At the same time, the only factor that influences some of the main quantitative parameters of the male's sexual behavior (frequency of ejaculation, frequency of mounts with intromission) and defines successful copulation is the taxon of males. This means that during encounters of heterospecific sexual partners of $M$. musculus and mice from Trans-Caucasia the pattern of sexual behavior of heterospecific males which differs from that of conspecific ones may provoke incomplete or unsuccessful copulation. As result of, these quantitative differences may represent (on an evolutionary scale) one of the driving forces behind the reproductive isolation of Trans-Caucasian mice from M. musculus. Earlier we demonstrated that different stereotypes of mating behavior prevent successful copulation completely in sympatric species M. musculus and M. spicilegus and can be one of the mechanisms of precopulatory isolation (Ambaryan et $a l ., 2019)$. The difference in the stereotype of the sexual behavior of these two species is based on significant differences in quantitative indicators.

As mentioned above, the hybrid zone in Trans-Caucasia is quite extensive (about $350,000 \mathrm{~km}^{2}$ ) and inhabited by numerous populations of hybrids. According to the current state of research, the populations of the Trans-Caucasian region are much older than that of the differentiated species of synanthropic house mice (Milishnikov et al., 2004) and they are genealogically 
Table 9. Differences in sexual behavior duration and frequency of sexual behavior elements by categories of taxonomic identity and type of encounters.

\begin{tabular}{|c|c|c|c|}
\hline Paired comparisons & Median & U statistic & The level of significance $(p)$ \\
\hline \multicolumn{4}{|c|}{ Attempts to mount (frequency) } \\
\hline $\begin{array}{l}1-\text { M. musculus, } \\
2 \text { - mice from Trans-Caucasia }\end{array}$ & $\begin{array}{l}1-29 \\
2-25\end{array}$ & 160 & 0.285 \\
\hline $\begin{array}{l}1 \text { - conspecific partner, } \\
2-\text { heterospecific partner }\end{array}$ & $\begin{array}{c}1-31.5 \\
2-22\end{array}$ & 158 & 0.261 \\
\hline \multicolumn{4}{|c|}{ Ejaculation (frequency) } \\
\hline $\begin{array}{l}1-\text { M. musculus, } \\
2 \text { - mice from Trans-Caucasia }\end{array}$ & $\begin{array}{l}1-2 \\
2-1\end{array}$ & 130 & $0.031 *$ \\
\hline $\begin{array}{l}1 \text { - conspecific partner, } \\
2 \text { - heterospecific partner }\end{array}$ & $\begin{array}{c}1-1.5 \\
2-1\end{array}$ & 155.5 & 0.171 \\
\hline \multicolumn{4}{|c|}{ Genital lock (frequency) } \\
\hline $\begin{array}{l}1-\text { M. musculus, } \\
2 \text { - mice from Trans-Caucasia }\end{array}$ & $\begin{array}{c}1-0.5 \\
2-0\end{array}$ & 115 & $0.004 *$ \\
\hline $\begin{array}{l}1 \text { - conspecific partner, } \\
2-\text { heterospecific partner }\end{array}$ & $\begin{array}{l}1-0 \\
2-0\end{array}$ & 186 & 0.642 \\
\hline \multicolumn{4}{|c|}{ Mounts with intromission (frequency) } \\
\hline $\begin{array}{l}1-\text { M. musculus, } \\
2 \text { - mice from Trans-Caucasia }\end{array}$ & $\begin{array}{l}1-0 \\
2-0\end{array}$ & 141.5 & $0.024 *$ \\
\hline $\begin{array}{l}1 \text { - conspecific partner, } \\
2-\text { heterospecific partner }\end{array}$ & $\begin{array}{l}1-0 \\
2-0\end{array}$ & 183 & 0.522 \\
\hline \multicolumn{4}{|c|}{ Mounts without intromission (frequency) } \\
\hline $\begin{array}{l}1-\text { M. musculus, } \\
2-\text { mice from Trans-Caucasia }\end{array}$ & $\begin{array}{c}1-18.5 \\
2-19 \\
\end{array}$ & 196.5 & 0.935 \\
\hline $\begin{array}{l}1 \text { - conspecific partner, } \\
2 \text { - heterospecific partner }\end{array}$ & $\begin{array}{l}1-21 \\
2-17.5\end{array}$ & 187.5 & 0.745 \\
\hline \multicolumn{4}{|c|}{ Mounts with intromission and thrusts (frequency) } \\
\hline $\begin{array}{l}1-\text { M. musculus, } \\
2 \text { - mice from Trans-Caucasia }\end{array}$ & $\begin{array}{l}1-15 \\
2-18.5 \\
\end{array}$ & 198 & 0.968 \\
\hline $\begin{array}{l}1-\text { conspecific partner, } \\
2-\text { heterospecific partner }\end{array}$ & $\begin{array}{l}1-17.5 \\
2-15.5 \\
\end{array}$ & 187.5 & 0.745 \\
\hline \multicolumn{4}{|c|}{ Duration of sexual behavior } \\
\hline $\begin{array}{l}1-\text { M. musculus, } \\
2-\text { mice from Trans-Caucasia }\end{array}$ & $\begin{array}{l}1-199.58 \\
2-218.22 \\
\end{array}$ & 196 & 0.925 \\
\hline $\begin{array}{l}1 \text { - conspecific partner, } \\
2-\text { heterospecific partner }\end{array}$ & $\begin{array}{l}1-261.9 \\
2-181.72\end{array}$ & 124 & $0.041^{*}$ \\
\hline
\end{tabular}

closely related to the ancient Central Asian form of M. musculus s. str. This Central Asian form separated both $M$. domesticus and M. castaneus from a common ancestor and preserved the undifferentiated gene pool (Milishnikov et al., 2004). These assumptions allow the participation of differentiated species of synanthropic house mice in the final formation of the gene pool of modern Trans-Caucasian populations. This hybrid zone was apparently formed both during the dispersal of the ancestral form, before it changed the lifestyle from free-living to synanthropic, and in a later period as a result of invasions of $M$. domesticus and $M$. musculus species by means of man and their hybridization with the ancient form (Milishnikov, 2004; Milishnikov et al., 2004; Cucchi et al., 2013). The specific pattern of sexual behavior of mice from Trans-Caucasia can be considered a consequence of adaptation to the local environmental conditions and could have arisen as a by-product of the allopatric divergence of populations.

Current research shows that males of house mice from the European hybrid zone have reduced fertility (Albrechtová et al., 2012; Turner et al., 2012). The progeny of laboratory crosses between $M$. domesticus and M. musculus also have reduced fertility (Forejt \& Ivanyi, 1974; Britton-Davidian et al., 2005; Good et al., 2008; Mihola et al., 2009; White et al., 2011; Suzuki \& Nachman, 2015). This confirms the generally accepted view that hybridization of closely related taxa is a negative phenomenon, because it disrupts the balance of the coadapted gene complexes, causing reduced fitness of the hybrids and their full or partial sterility (Arnold, 1997). In the wild, hybridization can either 
facilitate or prevent speciation (Mallet, 2007; Bank et al., 2011; Schulte et al., 2012). If hybridization is not adaptive, selection is expected to favor the evolution of assortative mate preference in the two hybridizing populations, a process called reinforcement (Jaenike et al., 2006; Nosil et al., 2007). One of the indicators of reduced fitness of hybrid genotypes could be behavior changes or deploying of unattractive signals, that distort communication between potential sexual partners. These changes appear when new associations of alleles are brought together by hybridization (Latour et al., 2013; Uy et al., 2018), and sexual selection can act against such behavior and signals. Misinterpreted signals lead to distorted communication and diminished sexual motivation and activity of hybrids (especially males) toward other hybrids or individuals of parental species and may prevent subsequent crossing and backcrossing of hybrids. The pattern of sexual behavior of hybrid males in voles (Microtus socialis goriensis $\times M$. hartingi and M. s. socialis $\times$ M. paradoxus) significantly differs from that of parental species (Zorenko, 2013). Specifically, quantitative parameters of copulation in hybrids were in most cases lower and sexual behavior as whole was less intense than in parental forms of voles: males exhibited significantly fewer series of copulation, decreased or increased level of genital stimulation, longer duration of copulation and longer period of rest between consecutive bouts. However, it is theoretically impossible to reject the selective advantage of hybrid individuals under certain conditions. The debate concerning the importance and prevalence of homoploid hybrid speciation as a general speciation mechanism continues (Mavárez \& Linares, 2008; Arnold \& Martin, 2010; Schumer et al., 2014, 2018; Feliner et al., 2017; Comeault \& Matute, 2018).

Nevertheless, according to our investigation, hybrid mice from Trans-Caucasia and M. musculus from the Moscow and the Moscow region had similar reproduction intensity in laboratory conditions (Kotenkova et al., 2018). We demonstrated relatively high mortality of young in some variants of crosses, but we did not find serious confirmation of any postcopulatory isolating mechanisms contributing to separation of Trans-Caucasian mice from M. musculus (Kotenkova et al., 2018). The results of this study confirm the genetic proximity of the house mice from Trans-Caucasia and M. musculus. Both forms are easily crossed in the laboratory. There was no decrease in viability and fecundity in $\mathrm{F}_{1}$ hybrids, although in some variants of crosses there was an increased mortality of pups. There is also absent any strong evidence of reduction of fitness and fecundity of Trans-Caucasian house mice. The indicators of their fecundity are quite high for their entire populated territory. In eastern Trans-Caucasia the number of embryos in females varies from 1 to 11 ; on average, it is 5.6 (Eigelis, 1980). In Armenia the number of embryos varied from 1 to 10 in different months, on average, 5.0-7.0 (Alieva, 1965). These fertility rates do not differ significantly from those for other regions where $M$. musculus lives, including the North Caucasus. According to Tembotov \& Shkhashamiev (1984), the number of embryos per female in Kabardino-Balkaria ranges from 4 to 14 . We did not observe any significant differences in the rates of reproduction under laboratory conditions between mice from Yerevan and M. musculus from different populations (Maltsev et al., 2015). Trans-Caucasian house mice were numerous in different habitats and can breed throughout the year according to results of studies conducted in the middle and end of the last century (Alieva, 1965; Alekperov, 1966; Eigelis, 1980). All obtained data suggest that populations of mice from Trans-Caucasia have enough viability to survive and inhabit the region. This means that complicated evolutionary origin of populations of mice from Trans-Caucasia does not confine their adaptability and ultimately their evolutionary success.

Comparison of our previous and current data leads to the conclusion that quantitative features of sexual behavior (especially frequency of ejaculations) of sympatric species M. musculus and M. spicilegus differ much more than those of M. musculus and Trans-Caucasian mice. Different stereotypes of mating behavior during the heterospecific encounter of potential sexual partners can disturb the communicative process and prevent successful copulation of M. musculus and M. spicilegus (Ambaryan et al., 2019). Previously, we demonstrated that $M$. musculus and $M$. spicilegus clearly distinguish con- and heterospecific individuals by odor, preferring the odor of conspecifics (Kotenkova et al., 1989b; Kotenkova \& Naidenko, 1999). Moreover, the preference of the odor of conspecific sexual partners is formed in ontogenesis under the influence of early olfactory experience (Kotenkova et al., 2019). Thus, precopulatory isolation of these species is based both on significant differences in sexual behavior and on response to the odor. At the same time differences in sexual behavior can derive from differences in mating systems of closely related sympatric species of house mice. It is well known that the mating system of the commensal taxa of house mice (M. musculus, M. domesticus) may be considered as polygamous (Crowcroft, 1955; Mackintosh, 1981; Wolf, 1985; Kotenkova \& Munteanu, 2006), while the mating system of wild-living, mound-building mice (M. spicilegus) is generally viewed as monogamous (Dobson \& Baudoin, 2002; Patris et al., 2002; Poteaux et al., 2008). This entire picture is complicated by the fact that the level of sperm competition as well as efficacy of sexual behavior is drastically different in these two species of house mice. These disparities probably stem from the specificity of ecological conditions and differences in the spatiotemporal structure of social groups in these sympatric species (Ambaryan et al., 2019). Therefore, all these social and physiological factors may reduce the odds of encounter between heterospecific sexual partners, the efficacy of sexual behavior during that encounter and the mating success in general. Experimental selection of $M$. domesticus confirms this suggestion: after 24 generations, males from groups with polygamous breeding and with a high level of sperm competition had testes with a higher proportion of seminiferous tubules compared to males reared in groups with monogamous breeding (Firman et al., 2015). Also, it has been shown that after 
8 generations of selection in lines of $M$. domesticus, differing only by breeding system (polygamous or monogamous lines), males in polygamous lines (marked by a high level of sperm competition) had greater numbers of epididymal sperm and increased sperm motility, compared to males from monogamous lines. This was accompanied by the correlated response of increased litter size in females in polygamous lines (Firman \& Simmons, 2009). However, it should be noted that M. musculus and mice from Trans-Caucasia have the same polygamous breeding system. Consequently, this factor should be excluded from factors that affect the mechanisms of precopulatory isolation.

In parapatric taxa (M. m. wagneri and M. m. muscu$l u s$ ), differences of sexual behavior are insignificant (Ambaryan et al., 2015); however, experimental hybridization of $M$. m. musculus (male) $\times M$. m. wagneri (female) revealed a decrease in the intensity of reproduction and the non-viability of the pups. These data suggest the initial stages of the development of postcopulatory isolation between these taxa (Maltsev et al., 2016).

We summarize that differences in the patterns of sexual behavior of closely related forms of house mice may lead to distorted communication between heterospecific partners which, in evolutionary perspective, may contribute to the formation of precopulatory barriers between closely related forms of house mice, including M. musculus and populations of Trans-Caucasia.

ACKNOWLEDGEMENTS. This research was supported by project AAAA-A18-118042690110-1 "Ecological and evolutionary aspects of animal behavior and communication" of the Ministry of Education and Science of Russia. We thank Dr. M. Rodova (retired person, USA) for improving English of our manuscript.

\section{References}

Albrechtová J., Albrecht T., Baird S.J.E., Macholán M., Rudolfsen G., Munclinger P., Tucker P.K. \& Piálek J. 2012. Sperm-related phenotypes implicated in both maintenance and breakdown of a natural species barrier in the house mouse // Proceedings of the Royal Society B, Biological Sciences. Vol.279. No.1748. P.4803-4810.

Alekperov Kh.M. 1966. [Mammals of Southwestern Azerbaijan]. Baku: Akademiya Nauk Azerbaidzhanskoi SSR. 147 p. [in Russian].

Alieva Sh.B. 1965. [Materials on the fauna and ecology of rodents of Nakhichevan ASSR] // Turaev D.G. (ed.). [Fauna and Ecology of Terrestrial Vertebrates of Azerbaijan]. Baku: Akademiya Nauk Azerbaidzhanskoi SSR. P.133-164 [in Russian].

Ambaryan A.V. \& Kotenkova E.V. 2008. [A comparative analysis of sexual behavior of Mus musculus and Mus spicilegus] // Uspechi Sovremennoi Biologii. Vol.128. No.2. P.199-214 [in Russian, with English summary].

Ambaryan A.V., Maltzev A.N. \& Kotenkova E.V. 2015. [Relationship between characteristics of sexual behavior and male sperm competitive ability in taxa of superspecies complex Mus musculus sensu lato] // Zhurnal Obshchei
Biologii. Vol.76. No.3. P.212-224 [in Russian, with English summary].

Ambaryan A.V., Voznessenskaya V.V. \& Kotenkova E.V. 2019. Mating behavior differences in monogamous and polygamous sympatric closely related species Mus musculus and Mus spicilegus and their role in behavioral precopulatory isolation // Russian Journal of Theriology. Vol.18. No.2. P.67-79.

Arnold M.L. 1997. Natural Hybridization and Evolution. New York: Oxford University Press. 228 p.

Arnold M.L. \& Martin N.H. 2010. Hybrid fitness across time and habitats // Trends in Ecology \& Evolution. Vol.25. No.9. P.530-536.

Baack E.J. \& Rieseberg L.H. 2007. A genomic view of introgression and hybrid speciation // Current Opinion in Genetics \& Development. Vol.17. No.6. P.513-518.

Bank C., Hermisson J. \& Kirkpatrick M. 2011. Can reinforcement complete speciation? // Evolution. Vol.66. No.1. P.229-239.

Barton N.Y. 2001. The role of hybridization in evolution // Molecular Ecology. Vol.10. No.3. P.551-568.

Batty J. 1978a. Acute changes in plasma testosterone levels and their relation to measures of sexual behaviour in the male house mouse (Mus musculus) // Animal Behaviour. Vol.26. No.2. P.349-357.

Batty J. 1978b. Plasma levels of testosterone and male sexual behaviour in strains of the house mouse (Mus musculus) // Animal Behaviour. Vol.26. No.2. P.339-348.

Beach F.A. 1976. Sexual attractivity, proceptivity, and receptivity in female mammals // Hormones and Behavior. Vol.7. No.7. P.105-138.

Bímová B., Macholán M., Baird S.J.E., Munclinger P., Dufková P., Laukaitis C.M., Karn R.C., Luzynski K., Tucker P.K. \& Piálek J. 2011. Reinforcement selection acting on the European house mouse hybrid zone // Molecular Ecology. Vol.20. No.11. P.2403-2424

Bonhomme F., Anand R., Darviche D., Din W. \& Boursot P. 1994. The mouse as a ring species? // Moriwaki K., Shiroishi T. \& Yonekawa H. (eds.). Genetics in Wild Mice. Its application to Biomedical Research. Tokyo: Japan Scientific Societies Press. P.13-23.

Borkin L.Ya. \& Litvinchuk S.N. 2013. [Hybridization, Speciation, and Systematics of Animals]. Alimov A.F. \& Stepan'yants S.D. (eds.). [Current Problems of Biological Taxonomy]. Trudy Zoologicheskogo Instituta AN SSSR. Suppl. No.2. Saint Petersburg: KMK Sci Press. P.83-139 [in Russian, with English summary].

Boursot P., Auffray J-C., Britton-Davidian J. \& Bonhomme F. 1993. The evolution of house mice // Annual Review of Ecology, Evolution, and Systematics. Vol.24. P.119-152.

Britton-Davidian J., Fel-Clair F., Lopez J., Alibert P. \& Boursot P. 2005. Postzygotic isolation between the two European subspecies of the house mouse: estimates from fertility patterns in wild and laboratory-bred hybrids // Biological Journal of the Linnean Society. Vol.84. No.3. P.379-393.

Canastar A. \& Maxson S.C. 2003. Sexual aggression in mice: effects of male strain and of female estrous state // Behavior Genetics. Vol.33. No.5. P.521-528.

Comeault A.A. \& Matute D.R. 2018. Genetic divergence and the number of hybridizing species affect the path to homoploid hybrid speciation // Proceedings of the National Academy of Sciences of USA. Vol.115. No.39. P.9761-9766. 
Crowcroft P. 1955. Social organization in wild mouse colonies // British Journal of Animal Behaviour. Vol.3. No.1. P.1-36.

Cucchi T., Kovács Z., Berthon R., Orth A., Bonhomme F., Evin A., Siahsarvie R., Darvish J., Bakhshaliyev V. \& Marro C. 2013. On the trail of Neolithic mice and men towards Transcaucasia: zooarchaeological clues from Nakhchivan (Azerbaijan) // Biological Journal of the Linnean Society. Vo.108. No.4. P.917-928.

Dewsbury D.A., Oglesby J.M., Sandra L., Shea S.L., James L. \& Connor J.L. 1979. Inbreeding and copulatory behavior in house mice: a further consideration // Behavior Genetics. Vol.9. No.3. P.151-163.

Dobson F.S. \& Baudoin C. 2002. Experimental tests of spatial association and kinship in monogamous mice (Mus spicilegus) and polygamous mice (Mus musculus domesticus) // Canadian Journal of Zoology. Vol.80. No.6. P.980-986.

Eigelis Yu.K. 1980. [Rodents of Eastern Trans-Caucasia and the Problem of Rehabilitation of Local Foci of Plague]. Saratov: Saratov University Press. 262 p. [in Russian].

Estep D.Q., Lanier D.L. \& Dewsbury D.A. 1975. Copulatory behavior and nest building behavior of wild house mice (Mus musculus) // Animal Learning \& Behavior. Vol.3. No.4. P.329-336.

Feliner G.N., Alvarez I., Fuertes-Aguilar J., Heuertz M., Marques I., Moharrek F., Pineiro R., Riina R., Rossello J.A., Soltis P.S. \& Villa-Machío I. 2017. Is homoploid hybrid speciation that rare? An empiricist's view // Heredity. Vol.118. No.6. P.513-516.

Firman R.C. \& Simmons L.W. 2009. Experimental evolution of sperm quality via postcopulatory sexual selection in house mice // Evolution. Vol.64. No.5. P.1245-1256.

Firman R.C., Garcia-Gonzalez F., Thyer E., Wheeler S., Yamin Z., Yuan M. \& Simmons L.W. 2015. Evolutionary changes in testes tissue composition among experimental populations of house mice // Evolution. Vol.69. No.3. P.848-855

Forejt J. \& Ivanyi P. 1974. Genetic studies on male sterility of hybrids between laboratory and wild mice (Mus musculus L.) // Genetics Research. Vol.24. No.2. P.189-206.

Frisman L.V., Korobitsina K.V., Yakimenko L.V., Bokshtein F.M. \& Muntyanu A.I. 1990. Genetic differentiation of the U.S.S.R. house mice: electrophoretic study of proteins // Biological Journal of the Linnean Society. Vol.41. Nos 1-3. P.65-72.

Good J.M., Handel M.A. \& Nachman M.W. 2008. Asymmetry and polymorphism of hybrid male sterility during the early stages of speciation in house mice // Evolution. Vol.62. No.1. P.50-65.

Hewitt G.M. 2001. Speciation, hybrid zones and phylogeography - or seeing genes in space and time // Molecular Ecology. Vol.10. No.3. P.537-549.

Jaenike J., Dyer K.A., Cornish C. \& Minhas M.S. 2006 Asymmetrical reinforcement and Wolbachia infection in Drosophila // PLoS Biology. Vol.4. No.10. P.1852-1862.

Kotenkova E.V. \& Munteanu A.I. 2006. [A comparative analysis of the spatial-ethological population structure of different species of house mice related to their mode of life] // Uspekhi Sovremennoi Biologii. Vol.126. No.5. P.513-528 [in Russian, with English summary].

Kotenkova E.V. \& Naidenko S.V. 1999. Discrimination of con- and heterospecific odors in different taxa of the Mus musculus species group: olfactory cues as precopulatory isolating mechanism // Johnston R.E., Muller-Schwarze D. \& Sorensen P. (eds.). Advances in Chemical Communication in Vertebrates. New York: Plenum Press. P.299-308.

Kotenkova E.V., Mal'tsev A.N. \& Ambaryan A.V. 2018. Experimental analysis of the reproductive potential of house mice (Mus musculus sensu lato, Rodentia, Muridae) in Transcaucasia and other regions // Biology Bulletin. Vol.45. No.8. P.884-897.

Kotenkova E.V., Osadchuck A.V. \& Lyalyukhina S.I. 1989b. Precopulatory isolating mechanisms between the house and mound-building mouse // Acta Theriologica. Vol.34. No.22. P.315-324.

Kotenkova E.V., Osipova O.V. \& Lyalyukhina S.I. 1989a. [Behavioral elements and seasonal changes of behavior in mound-building mice (Mus hortulanus Nordm.)] // Sokolov V.E., Kotenkova E.V., Krasnov B.R. \& Meshkova N.N. (eds.). The House Mouse. Moscow: Institute of Evolutionary Animal Morphology and Ecology Press. P.256-272 [in Russian, with English summary].

Kotenkova E., Romachenko A., Ambaryan A. \& Maltsev A. 2019. Effect of early experience on neuronal and behavioral responses to con- and heterospecific odors in closely related Mus taxa: epigenetic contribution in formation of precopulatory isolation // BMC Evolutionary Biology. Vol.19. P.51.

Latour Y. \& Ganem G. 2017. Does competitive interaction drive species recognition in a house mouse secondary contact zone? // Behavioral Ecology. Vol.28. No.1. P.212-221.

Latour Y., Perriat-Sanguinet M., Caminade P., Boursot P., Smadja C.M. \& Ganem G. 2013. Sexual selection against natural hybrids may contribute to reinforcement in a house mouse hybrid zone // Proceedings of the Royal Society B, Biological Sciences. Vol.281. No.1776. e.20132733.

Levenets J.V., Panteleeva S.N., Reznikova Zh.I., Gureeva A.V., Feoktistova N.Y. \& Surov A.V. 2019. Experimental comparative analysis of hunting behavior of four species of Cricetinae hamsters // Zoologicheskii Zhurnal. Vol.98. No.6. P.673-683 [in Russian, with English summary].

Mackintosh J.H. 1981. Behaviour of house mouse // Symposia of the Zoological Society of London. Vol.47. P.337-365.

Mallet J. 2007. Hybrid speciation// Nature. Vol.446. No.7133. P.279-283.

Maltsev A.N., Ambaryan A.V., Bazhenov U.A. \& Kotenkova E.V. 2016. Experimental hybridization and an evaluation of the fertility of some forms of the house mouse supraspecies complex Mus musculus (Rodentia, Muridae)// Biology Bulletin. Vol.43. No.7. P.747-757.

Maltsev A.N., Stakheev V.V., Bogdanov A.S., Fomina E.S. \& Kotenkova E.V. 2015. Phylogenetic relationships of intraspecific forms of the house mouse Mus musculus: Analysis of variability of the control region (D-loop) of mitochondrial DNA// Doklady Biological Sciences. Vol.465. No.3. P.285-288.

Mavárez J. \& Linares M. 2008. Homoploid hybrid speciation in animals // Molecular Ecology. Vol.17. No.19. P.4181-4185.

McGill T.E. 1962. Sexual behavior in three inbred strains of mice // Behaviour. Vol.19. No.4. P.341-350.

Mezhzherin S.V. \& Kotenkova E.V. 1989. [Genetic marking of the house mouse subspecies of the USSR fauna] // Doklady Akademii Nauk SSSR. Vol.304. No.5. P.1271-1275 [in Russian]. 
Mezhzherin S.V., Kotenkova E.V. \& Mikhailenko A.G. 1998. The house mice, Mus musculus s. 1., hybrid zone of Trans-Caucasus // Zeitschrift für Säugetierkunde. Bd.63. Hf.2. S.154-168.

Mihola O., Trachtulec Z., Vlcek C., Schimenti J.C. \& Forejt J. 2009. A mouse speciation gene encodes a meiotic histone h3 methyltransferase // Science. Vol.323. No.5912. P.373-375.

Milishnikov A.N. 2004. Differentiation between the ancestral and evolutionarily new polymorphism in populations of the superspecies complex of house mice Mus musculus sensu lato // Doklady Biological Sciences. Vol.397. No.2. P.317-320.

Milishnikov A.N., Lavrenchenko L.A. \& Lebedev V.S. 2004 Origin of the house mice (superspecies complex Mus musculus sensu lato) from the Transcaucasia region: a new look at dispersal routes and evolution // Russian Journal of Genetics. Vol.40. No.9. P.1011-1026.

Milishnikov A.N., Rafiev A.N., Lavrenchenko L.A. \& Orlov V.N. 1990. High level of introgression of Mus domesticus genes in a Transcaucasian population of Mus musculus s. str. // Doklady Biological Sciences. Vol.311. No.3. P.279-282.

Mosig D.W. \& Dewsbury D.A. 1976. Studies of the copulatory behavior of house mice (Mus musculus) // Behavioral Biology. Vol.16. No.4. P.463-473.

Nelson J.F., Felicio L.S., Randall P.K., Sims C. \& Finch C.E. 1982. A longitudinal study of estrous cyclicity in aging C57BL/6J mice: I. Cycle frequency, length and vaginal cytology // Biology of Reproduction. Vol.27. No.2. P.327-339.

Niel L. \& Monks D.A. 2013. Mouse sex: sexual differentiation and sexual behavior in Mus musculus //Crusio W.E., Sluyter F., Gerlai R.T. \& Pietropaolo S. (eds.). Behavioral Genetics of the Mouse. Vol.1. Genetics of Behavioral Phenotypes. Cambridge: Cambridge University Press. P.218-229.

Nosil P., Crespi B.J., Gries R. \& Gries G. 2007. Natural selection and divergence in mate preference during speciation // Genetica. Vol.128. No.3. P.309-327.

Orth A., Lyapunova E., Kandaurov A., Boissinot S., Boursot P., Vorontsov N. \& Bonhomme F. 1996. L'espèce polytypique Mus musculus en Transcaucasie // Comptes Rendus de l'Académie des Sciences. Series III. Sciences de la Vie. Vol.319. No.5. P.435-441.

Panteleeva S.N., Levenets J.V., Novikovskaya A.A., Reznikova Zh.I., Lopatina N.V. \& Litvinov Yu.N. 2020. Experimental investigation of the hunting behavior in mountain voles Alticola strelzowi and Alticola tuvinicus (Rodentia, Cricetidae) // Zoologicheskii Zhurnal. Vol.99. No.1. P.113-120 [in Russian, with English summary].

Park J.H. 2011. Assessment of male sexual behavior in mice // Todd D.G. (ed.). Mood and Anxiety Related Phenotypes in Mice: Characterization Using Behavioral Tests. Vol.2. New York: Humana Press. P.357-373.

Patris B., Gouat P., Jacquot C., Christophe N. \& Baudoin C. 2002. Agonistic and sociable behaviors in the mound-building mouse, Mus spicilegus, a comparative study with Mus musculus domesticus // Aggressive Behavior. Vol.28. No.1. P.75-84.
Poteaux C., Busquet N., Gouat P., Katona K. \& Baudoin C. 2008. Socio-genetic structure of mound-building mice, Mus spicilegus, in autumn and early spring // Biological Journal of the Linnean Society. Vol.93. No.4. P.689-699.

Rieseberg L.H. 1997. Hybrid origins of plant species // Annual Review of Ecology, Evolution, and Systematics. Vol.28. P.359-389.

Sage R.D., Atchley W.R. \& Capanna E. 1993. House mice as models in systematic biology // Systematic Biology. Vol.42. No.4. P.523-561.

Schulte U., Veith M. \& Hochkirch A. 2012. Rapid genetic assimilation of native wall lizard populations (Podarcis muralis) through extensive hybridization with introduced lineages // Molecular Ecology. Vol.21. No.17. P.4313-4326.

Schumer M., Rosenthal G.G. \& Andolfatto P. 2014. How common is homoploid hybrid speciation? // Evolution. Vol.68. No.6. P.1553-1560.

Schumer M., Rosenthal G.G. \& Andolfatto P. 2018. What do we mean when we talk about hybrid speciation? // Heredity. Vol.120. No.4. P.379-382.

Smadja C. \& Ganem G. 2005. Asymmetrical reproductive character displacement in the house mouse // Journal of Evolutionary Biology. Vol.18. No.6. P.1485-1493.

Stopka P. \& Macdonald D.W. 1998. Signal interchange during mating in the wood mouse Apodemus sylvaticus: The concept of active and passive signaling // Behaviour. Vol.135. No.2. P.231-249.

Stopka P. \& Macdonald D.W. 1999. The market effect in the wood mouse Apodemus sylvaticus: Selling information on reproductive status // Ethology. Vol.105. No.11. P.969-982.

Suzuki T.A. \& Nachman M.W. 2015. Speciation and reduced hybrid female fertility in house mice // Evolution. Vol.69. No.9. 2468-2481.

Tembotov A.K. \& Shkhashamiev Kh.K. 1984. [The Fauna of Kabardino-Balkaria]. Nalchik: Elbrus. 192 p. [in Russian].

Turner L.M., Schwahn D.J. \& Harr B. 2012. Reduced male fertility is common but highly variable in form and severity in a natural house mouse hybrid zone // Evolution. Vol.66. No.2. P.443-458.

Uy J.A.C., Irwin D.E. \& Webster M.S. 2018. Behavioral isolation and incipient speciation in birds // Annual Review of Ecology, Evolution, and Systematics. Vol.49. P.1-24.

Walkowa W., Kotenkova E., Adamczyk K. \& Barkowska M. 1998. Behavior of house mice in semi-natural conditions: influence of spatial separation and population size // Acta Theriologica. Vol.43. No.3. P.241-254.

White M.A., Steffy B., Wiltshire T. \& Payseur B.A. 2011. Genetic dissection of a key reproductive barrier between nascent species of house mice, Mus musculus domesticus and Mus musculus musculus // Genetics. Vol.189. No.1. P.289-304.

Wolf R.J. 1985. Mating behaviour and female choice: their relation to social structure in wild caught house mice (Mus musculus) housed in semi-natural environment // Journal of Zoology. Vol.207. No.1. P.43-51.

Zorenko T. 2013. [Social Voles of the Subgenus Sumeriomys: Systematics, Biology and Behaviour] Saarbrücken: Palmariun Academic Publishing. 548 p. [in Russian]. 